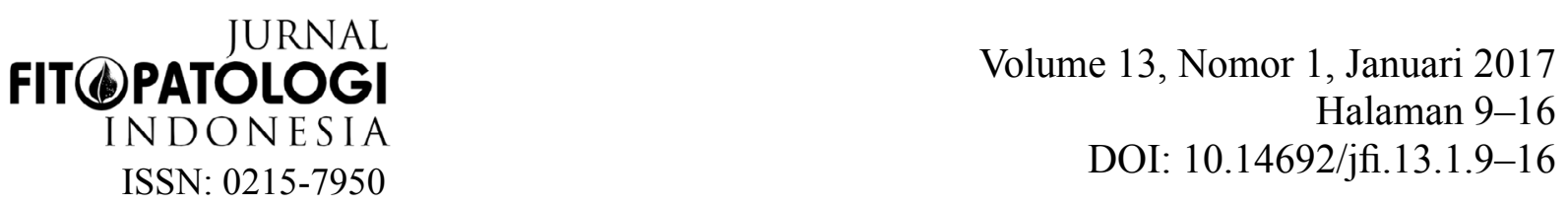

\title{
Keragaman Morfologi, Genetika, dan Patogenisitas \\ Colletotrichum acutatum Penyebab Antraknosa Cabai di Jawa dan Sumatera
}

\section{Morphology, Genetic, and Pathogenicity Variability of Coletotrichum acutatum The Causal Agent of Anthracnose on Chilli in Java and Sumatera}

\author{
Roy Ibrahim, Sri Hendrastuti Hidayat, Widodo* \\ Institut Pertanian Bogor, Bogor 16680
}

\begin{abstract}
ABSTRAK
Colletotrichum acutatum dikenal sebagai agens penyebab utama penyakit antraknosa cabai di Indonesia. Penelitian ini bertujuan menetukan variabilitas genetika C. acutatum di Jawa dan Sumatera berdasarkan karakter morfologi dan molekul, serta untuk mengevaluasi patogenisitas beberapa isolat. Pengamatan karakter morfologi meliputi warna dan pertumbuhan setiap koloni, serta bentuk dan ukuran konidium. Identifikasi molekuler melalui amplifikasi DNA menggunakan primer spesifik untuk C. acutatum, yaitu CaInt2/ITS4 dan analisis sikuen. Uji patogenesitas di laboratorium untuk setiap isolat dilakukan terhadap Capsicum annuum dan C. frutescens. Keragaman morfologi diamati pada 40 isolat C. acutatum. Sebagian besar isolat memiliki koloni putih/krem, bentuk konidium fusiform dengan panjang rata-rata $6.11-9.73 \mu \mathrm{m}$ dan lebar $2.24-2.73 \mu \mathrm{m}$. Uji patogenisitas 3 isolat $C$. acutatum menunjukkan variasi dari sedang sampai tinggi berdasarkan ukuran lesio pada cabai. Berdasarkan perunutan DNA 8 isolat C. acutatum dari Jawa dan Sumatera memiliki homologi yang tinggi.
\end{abstract}

Kata kunci: amplifikasi DNA, analisis sikuens, konidium, warna koloni

\begin{abstract}
Colletotrichum acutatum is known as the major causal agents of anthracnose disease of chilli pepper in Indonesia. This research was aimed to study genetic variability of C. acutatum in Java and Sumatera based on morphological and molecular characteristics and to evaluate pathogenicity of several isolates. Observation on morphological characteristics involved colour and growth of each colony as well as shape and size of conidia. Molecular identification was performed by DNA amplification using specific primer for $C$. acutatum, i.e. CaInt2/ITS4 followed by sequencing and nucleotide sequence analysis. Pathogenicity test for each isolate on Capsicum annuum and C. frutescens was conducted in the laboratory using detached chilli. Morphology variability was observed from 40 isolates of C. acutatum. Most of the isolates have white/beige colonies with fusiform conidia of 6.11-9.73 $\mu \mathrm{m}$ in length and 2.24-2.73 $\mu \mathrm{m}$ in width. Pathogenicity of 3 C. acutatum isolates varies from moderate to high based on lesions size on infected chilli. Sequence analysis of 8 C. acutatum isolates indicated high homology among isolates from Java and Sumatera.
\end{abstract}

Key words: colour of colony, conidium, DNA amplification, sequence analysis

*Alamat penulis korespondensi: Departemen Proteksi Tanaman, Fakultas Pertanian, Institut Pertanian Bogor. Jalan Kamper Kampus IPB Darmaga Bogor 16680.

Telp: 0251-8629364, Faks: 0251-862362, surel: widodo@apps.ipb.ac.id 


\section{PENDAHULUAN}

Cabai merupakan salah satu komoditas sayuran yang bernilai ekonomi tinggi di Indonesia. Menurut Badan Pusat Statistik produktivitas cabai nasional Indonesia tahun 2015 ialah 8.65 ton ha-1 (BPS 2015). Syukur et al. (2010) menyatakan bahwa produktivitas cabai mampu mencapai 13.11 ton ha ${ }^{-1}$. Hal ini menandakan bahwa produktivitas cabai di Indonesia masih di bawah potensi yang seharusnya. Salah satu faktor pembatas keberhasilan budi daya cabai ialah adanya gangguan hama dan penyakit.

Antraknosa merupakan penyakit utama dan dapat menurunkan hasil antara 20\% dan 90\% (Balitbangtan 2016). Antraknosa pada cabai dapat disebabkan oleh beberapa spesies cendawan Colletotrichum antara lain C. acutatum, C. capsici, C. coccodes, C. dematium, dan C. gloeosporioides (Park et al. 1990; Johnston dan Jones 1997; Kim et al. 1999; Sharma et al. 2005; Kim et al. 2007). Spesies $C$. acutatum adalah jenis yang paling dominan di Asia (AVRDC 2009).

Identifikasi spesies Colletotrichum dapat dilakukan secara morfologi, yaitu berdasarkan warna koloni, diameter koloni, bentuk konidium, dan ukuran konidium (Smith dan Black 1990; Than et al. 2008). Metode polymerase chain reaction (PCR) dan analisis sikuen nukleotida semakin banyak digunakan dalam proses identifikasi cendawan. PCRRAPD digunakan untuk membedakan C.capsici dan $C$. gloeosporioides penyebab antraknosa pada cabai di Thailand (Ratanacherdchai et al. 2007) dan penanda molekul 23032/1 serta 28487 untuk membedakan C. acutatum yang memiliki kesamaan warna koloni (Johnston dan Jones 1997).

Walaupun demikian, karakter morfologi masih tetap diperlukan untuk mempelajari keragaman suatu spesies cendawan. Penelitian ini bertujuan mendapatkan data informasi keragaman genetika C. acutatum berdasarkan karakter morfologi maupun molekuler dan mengetahui tingkat patogenisitas cendawan tersebut.

\section{BAHAN DAN METODE}

\section{Sampel Buah Cabai}

Sampel buah cabai yang terinfeksi antraknosa diambil dari pertanaman cabai di 12 kabupaten: Mandailing Natal (MN) (Sumatera Utara); Tanah Datar (TD), Payakumbuh (PYK), Agam (AGM) (Sumatera Barat); Kampar (KMP) (Riau); Bogor (BGR), Cianjur (CJR), Bandung Barat (BDG) (Jawa Barat); Brebes (BRB), Tegal (TGL) (Jawa Tengah); Blitar (BTR) (Jawa Timur); dan Bangli (BL) (Bali). Pengambilan sampel buah yang sakit dilakukan dengan metode purposive sampling. Sampel buah disimpan dalam kantong plastik secara terpisah dan dimasukkan ke dalam kotak penyimpanan sampel.

\section{Isolasi $C$. acutatum dari Buah Cabai}

Isolasi cendawan dari buah cabai terinfeksi dilakukan dengan mengambil biji dari masingmasing buah kemudian biji ditanam pada medium agar-agar dekstrosa kentang (ADK) yang sudah diberi asam laktat $20 \%$, selanjutnya diinkubasi pada suhu $25^{\circ} \mathrm{C}$. Pemurnian isolat cendawan dilakukan dengan metode spora tunggal (Choi et al. 1999). Sebanyak 7 biakan C. acutatum koleksi Klinik Tanaman dari beberapa kabupaten digunakan sebagai bahan pembanding penelitian, yaitu isolat-isolat asal Tanggamus (TGM) (Lampung); Garut (HGP) (Jawa Barat); Semarang (SMG) (Jawa Tengah), dan Mojokerto (MJK), Kediri (KD) (Jawa Timur).

\section{Identifikasi Morfologi $C$. acutatum}

Identifikasi morfologi cendawan dilakukan pada 10 hari setelah isolasi (HSI). Pengamatan makroskopi dilakukan terhadap warna koloni tampak atas dan bawah, serta diameter koloni pada medium ADK. Pengamatan mikroskopis meliputi bentuk, panjang, dan lebar konidium yang dipilih secara acak sebanyak 20 konidium (Than et al. 2008) untuk masingmasing isolat. Data pengamatan mikroskopis diolah menggunakan metode statistika analisis tabulasi silang dan uji lanjut chi-squere pada taraf 5\% dengan software tpsDig2. 


\section{Identifikasi Molekuler C. acutatum}

Biakan C. acutatum berumur 10 hari diambil sebanyak 3 potong koloni (diameter $\pm 5 \mathrm{~mm}$ ) menggunakan cork borer, kemudian dimasukkan ke dalam erlenmeyer $250 \mathrm{~mL}$ berisi medium cair dekstrosa kentang dan diinkubasi selama 7 hari pada suhu ruang. Miselium cendawan diambil dengan filtrasi vakum dan dicuci dengan akuades steril, selanjutnya dikeringanginkan. Ekstraksi DNA total mengikuti prosedur Sambrook et al. (1989) yang telah dimodifikasi. Sebanyak $0.2 \mathrm{~g}$ miselium digerus dengan nitrogen cair dan ditambahkan $1 \mathrm{~mL}$ bufer ekstrak dan $10 \mu \mathrm{L}$ $\beta$-mercapto-ethanol. Suspensi dimasukkan ke dalam tabung mikro, lalu diinkubasi dengan cara diapungkan pada penangas pada suhu $65{ }^{\circ} \mathrm{C}$ selama 30 menit, selanjutnya ditambahkan $750 \mu \mathrm{L}$ kloroform:isoamilalkohol (C:I) (24:1). Campuran tersebut disentrifugasi selama 10 menit pada kecepatan 11000 rpm. Supernatan yang diperoleh dipindahkan ke tabung mikro baru dan ditambahkan $1000 \mu \mathrm{L}$ isopropanol. Campuran tersebut diinkubasi selama 16 jam pada suhu $4{ }^{\circ} \mathrm{C}$ dan disentrifugasi pada kecepatan $12000 \mathrm{rpm}$. Benang DNA yang diperoleh disentrifugasi selama 10 menit. Supernatan dibuang dan pelet dicuci dengan etanol 70\%. Etanol dibuang dan pelet dikeringanginkan, selanjutnya diresuspensi dalam $100 \mu \mathrm{L}$ bufer TE dan disimpan pada suhu $-20{ }^{\circ} \mathrm{C}$.

Amplifikasi dilakukan menggunakan primer spesifik CaInt2 (5'-GGGG AAGCCTCTCGCGG-3') dan ITS4 ( 5' - TCCTCCGCTTATTGATATGC-3') dengan ukuran target $\pm 490 \mathrm{pb}$. Reaksi amplifikasi DNA dilakukan dengan volume total $25 \mu \mathrm{L}$ terdiri atas $2 \mu \mathrm{L} \mathrm{DNA}, 2.5 \mu \mathrm{L}$ bufer 10x dan $\mathrm{Mg}^{2+}, 0.5 \mu \mathrm{L}$ dNTP $10 \mathrm{mM}, 1 \mu \mathrm{L}$ masing-masing primer, $0.2 \mu \mathrm{L}$ Taq DNA (5 unit $\mu \mathrm{L}^{-1}$ ), dan $17.8 \mu \mathrm{L} \mathrm{H}_{2} \mathrm{O}$. Amplifikasi didahului dengan denaturasi awal pada $94{ }^{\circ} \mathrm{C}$ selama 5 menit, diikuti 30 siklus dengan tahapan denaturasi pada $94^{\circ} \mathrm{C}$ selama 1 menit, penempelan primer $45{ }^{\circ} \mathrm{C}$ selama 1 menit, sintesis DNA $72{ }^{\circ} \mathrm{C}$ selama 2 menit.

Hasil amplifikasi dianalisis dengan elektroforesis pada gel agarosa 1\%. Gel di rendam dalam larutan etidium bromida selama
15 menit, dilanjutkan dengan pembilasan di dalam air selama 10 menit. Hasil elektroforesis divisualisasikan dengan $U V$ transiluminator dan didokumentasikan.

Perunutan nukleotida dilakukan dengan mengirim produk amplifikasi ke PT Genetika Science Indonesia. Hasil perunutan nukleotida dibandingkan dengan data pada GenBank. Data yang berasal dari GenBank kemudian digunakan untuk analisis kesamaan menggunakan perangkat lunak BioEdit v.7.1.3. Hubungan kekerabatan antarisolat dikonstruksi menggunakan program MEGA v.6.06 berdasarkan algoritma Neighbor Joining dengan bootstrap 1000 kali.

\section{Uji Patogenisitas $C$. acutatum}

Uji patogenisitas menggunakan buah cabai C. annuum varietas Anies dan C. frutescens varietas Bonita yang sudah siap panen. Buah cabai disterilkan permukaannya dengan alkohol $70 \%$ selama 1 menit, kloroks $1 \%$ selama 1 menit, dan dibilas dengan akuades steril sebanyak 3 kali. Inokulasi cendawan pada permukaan buah dilakukan dengan meneteskan $5 \mu \mathrm{L}$ suspensi konidium $C$. acutatum dengan kerapatan $10^{5}$ konidium $\mathrm{mL}^{-1}$ pada luka tusukan dengan menggunakan jarum steril. Perlakuan menggunakan 6 buah cabai.

Buah cabai yang telah diberi perlakuan kemudian diinkubasi dalam wadah tertutup pada kondisi lembap dan suhu $25^{\circ} \mathrm{C}$. Peubah yang diamati ialah rata-rata ukuran lesio dan virulensi yang diukur pada 10 HSI. Skor patogenesitas dari 0-3 seperti pada Tabel 1.

\section{HASIL}

\section{Isolat $C$. acutatum dari Buah Cabai}

Sebanyak 42 isolat cendawan berhasil diperoleh dari buah cabai yang bergejala

Tabel 1 Skor dan kriteria patogenisitas isolat C. acutatum pada buah cabai.

\begin{tabular}{ccc}
\hline Skor & Ukuran lesio & Tingkat virulensi \\
\hline 0 & Tidak ada & Tidak virulen \\
1 & $<3 \mathrm{~mm}$ & Rendah \\
2 & $3-5 \mathrm{~mm}$ & Sedang \\
3 & $>5 \mathrm{~mm}$ & Tinggi \\
\hline
\end{tabular}


antraknosa. Isolat tersebut dan 7 isolat $C$. acutatum koleksi Klinik Tanaman diidentifikasi secara molekuler dengan metode PCR.

Penggunaan primer spesifik $C$. acutatum CaInt2/ITS4 pada isolat yang diuji menunjukkan adanya amplifikasi DNA pada 40 isolat dengan ukuran pita $\pm 490 \mathrm{pb}$, sedangkan pada 9 isolat lainnya tidak teramplifikasi (Gambar 1). Isolat koleksi Klinik Tanaman yang digunakan sebagai bahan pembanding menghasilkan pita DNA yang sama dengan ukuran pita $\pm 490 \mathrm{pb}$.

Identifikasi morfologi dilakukan terhadap 40 isolat $C$. acutatum yang telah diidentifikasi secara molekuler sebelumnya menunjukkan variasi warna yang cukup beragam. Tampak atas koloni berwarna putih dan abu-abu sedangkan tampak bawah berwarna krem, putih, peach, olive (Gambar 2). Sebanyak
52.5\% koloni yang tumbuh berwarna putih/ krem untuk tampak atas/bawah (Gambar 3).

Analisis tabulasi silang menunjukkan diameter koloni berkaitan nyata dengan warna koloni C. acutatum (Tabel 2). Koloni yang berwarna putih/krem memiliki pertumbuhan lebih cepat dibandingkan dengan koloni lainnya. Konidium dari 40 isolat pada umumnya berbentuk fusiform dengan ukuran rata-rata $6.11-9.73 \mu \mathrm{m} \times 2.24-2.73 \mu \mathrm{m}$.

\section{Filogenetikaa $C$. acutatum}

Sebanyak 8 isolat, yaitu AGM 1535, BGR 1602, BRB 07, KMP 1531, MN 1582, SMG 136, TGM 1101, BL 1603 dipilih untuk analisis filogenetika berdasarkan pada asal isolat (provinsi), warna dan diameter koloni. Isolat dari berbagai daerah di Jawa dan Sumatera membentuk satu kelompok (Gambar 4).

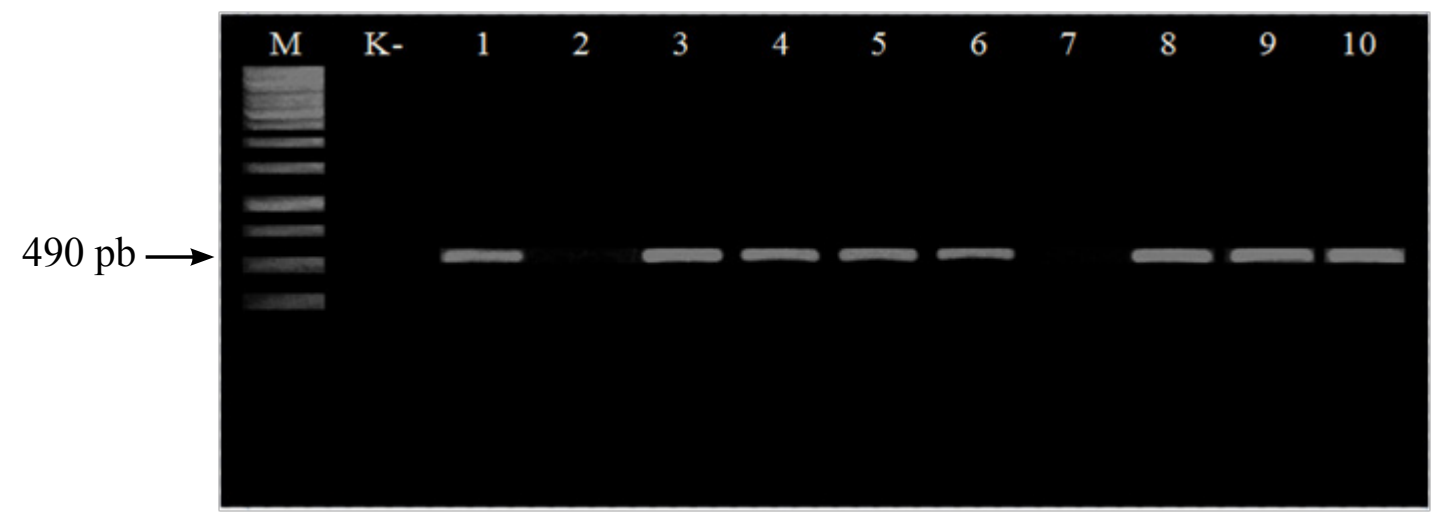

Gambar 1 Visualisasi pita DNA isolat-isolat Colletotrichum acutatum asal cabai hasil amplifikasi menggunakan pasangan primer CaInt2/ITS4. M, penanda DNA 1 kb ladder; K-, kontrol negatif; 1, AGM 1533; 2, BDG 1524; 3, BDG 1525; 4, HGP CA; 5, KMP 1531; 6, SMG 136; 7, SMG 137; 8, TD 1532; 9, TD 1534 dan; 10, TGM 1101.

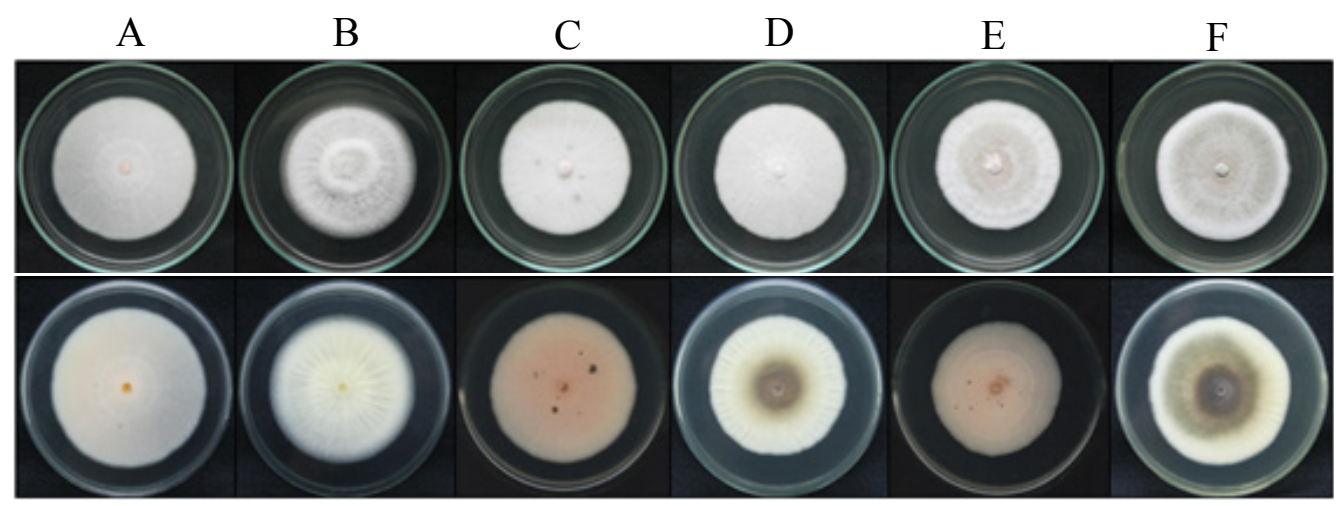

Gambar 2 Variasi warna koloni Colletotrichum acutatum penyebab antraknosa cabai tampak atas/bawah. A, putih/krem; B, putih/putih; C, putih/peach; D, putih/olive; E, abu-abu/peach; dan F, abu-abu/olive. 


\section{Patogenisitas C. acutatum}

Isolat dari Kabupaten Kampar, Riau (KMP 1531), Kabupaten Tanggamus, Lampung (TGM 1101), dan Kabupaten Brebes, Jawa Tengah (BRB 07) dipilih untuk uji patogenisitas. Pemilihan 3 isolat tersebut berdasarkan pada tempat asal isolat yang berbeda ketinggiannya. Inokulasi 3 isolat $C$. acutatum pada 2 spesies cabai menghasilkan ukuran lesio berkisar antara $3.66 \mathrm{~mm}$ dan

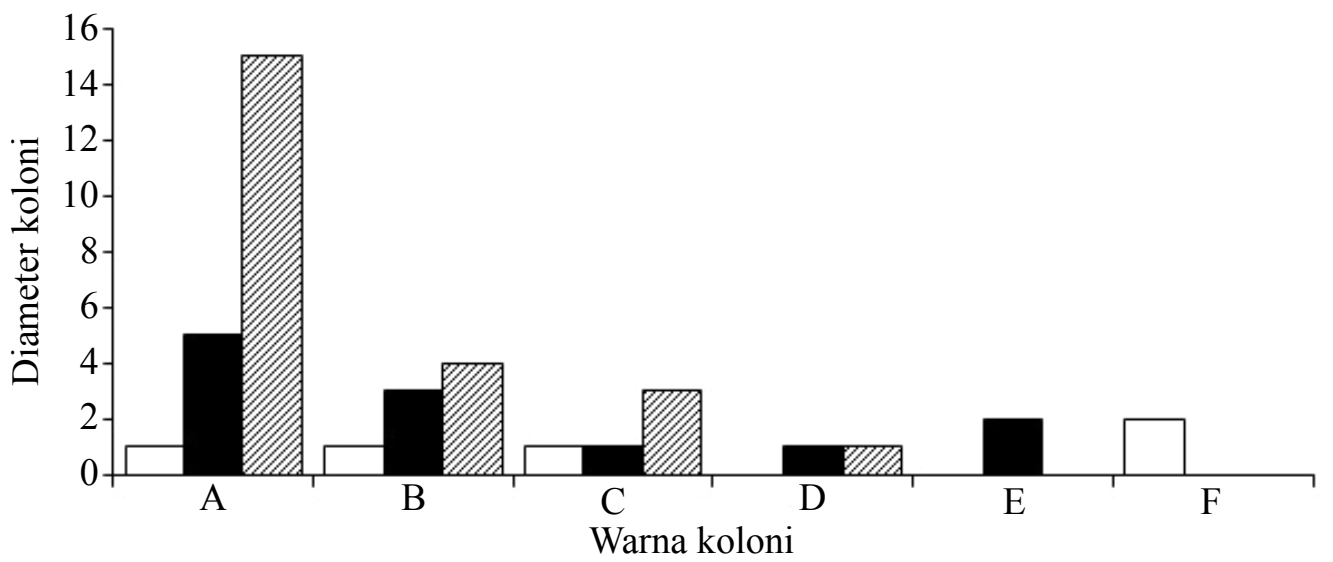

Gambar 3 Frekuensi jumlah koloni Colletotrichum acutatum berdasarkan ukuran diameter dan warna koloni. A, putih/ krem; B, putih/putih; C, putih/peach; D, putih/olive; E, abu-abu/peach; dan F, abu-abu/olive. $\square<49 \mathrm{~mm} ; \mathbf{\square}, 49-59 \mathrm{~mm}$; $\boldsymbol{\nabla},>59 \mathrm{~mm}$.

Tabel 2 Analisis tabulasi silang antara diameter koloni dan warna koloni Colletotrichum acutatum

\begin{tabular}{|c|c|c|c|c|c|c|c|c|}
\hline \multirow[t]{2}{*}{ Diameter koloni (mm) } & \multicolumn{6}{|c|}{ Warna koloni (atas/bawah) ${ }^{\mathrm{a}}$} & \multirow{2}{*}{$\mathrm{X}^{2}$} & \multirow{2}{*}{$\mathrm{P}^{\mathrm{b}}$} \\
\hline & A & $\mathrm{B}$ & $\mathrm{C}$ & $\mathrm{D}$ & $E$ & $\mathrm{~F}$ & & \\
\hline$<49$ & 1 & 1 & 1 & 0 & 0 & 2 & & \\
\hline $49-59$ & 5 & 3 & 1 & 1 & 2 & 0 & 21.81 & 0.01 \\
\hline$>59$ & 15 & 4 & 3 & 1 & 0 & 0 & & \\
\hline
\end{tabular}

${ }^{\mathrm{a}} \mathrm{A}$, putih/krem; B, putih/putih; C, putih/peach; D, putih/olive; E, abu-abu/peach; F, abu-abu/olive.

${ }^{\mathrm{b}}$ Nilai $\mathrm{P}<0.05$ menunjukkan ada hubungan antara diameter koloni dan warna koloni.

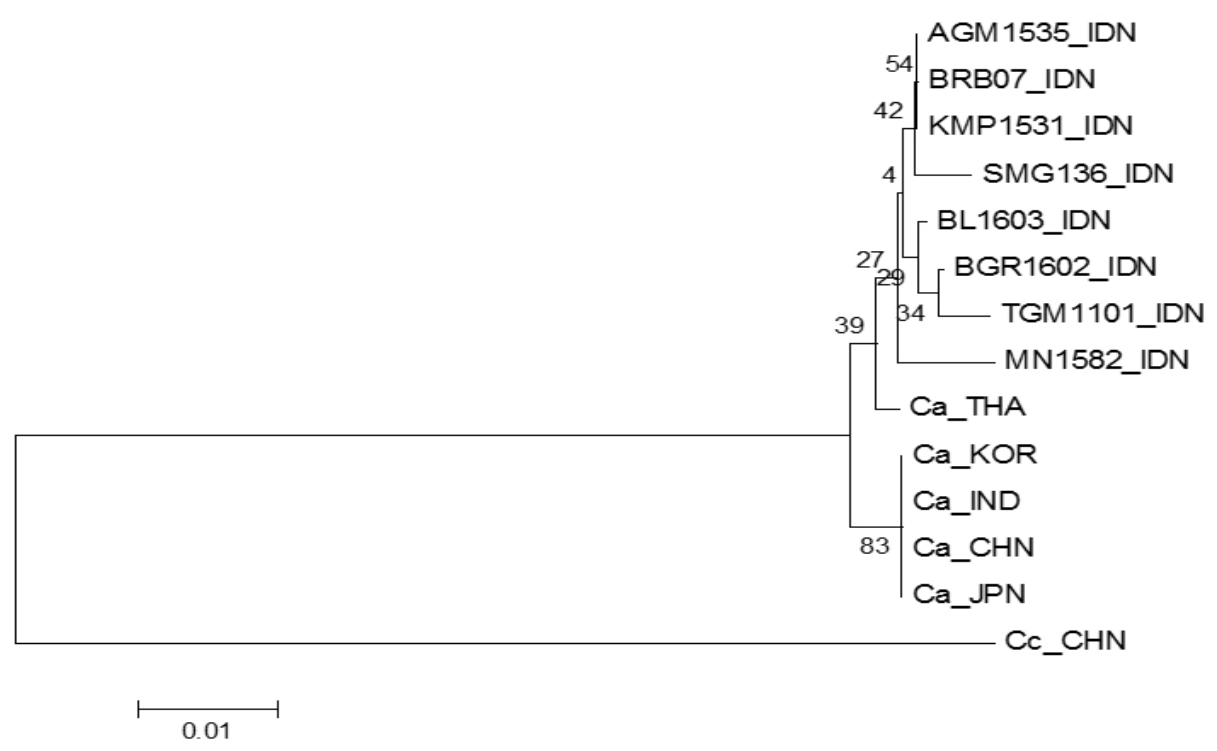

Gambar 4 Pohon filogenetika Colletotrichum acutatum dari berbagai daerah di Jawa dan Sumatera, yaitu BRB 07, KMP 1531, AGM 1535, MN 1582, SMG 136, BGR 1602, BL 1603, TGM 1101, dan beberapa negara di Asia (Thailand, Korea, India, China, dan Jepang). C. capsici (Cc_CHN_EF683602) digunakan sebagai pembanding di luar grup. 
$19.08 \mathrm{~mm}$ dengan tingkat virulensi sedang dan tinggi (Tabel 3). Isolat asal Kabupaten Brebes (BRB 07) menghasilkan ukuran lesio terbesar pada kedua spesies cabai, diikuti oleh isolat asal Kabupaten Tanggamus (TGM 1101) dan isolat asal Kabupaten Kampar (KMP 1531).

\section{PEMBAHASAN}

Penyakit antraknosa pada cabai menjadi masalah utama sehingga menyebabkan rendahnya produksi cabai di Indonesia. Keragaman morfologi telah banyak dilaporkan di antaranya cendawan $C$. acutatum memiliki warna koloni putih, merah muda, oranye muda sampai abu-abu (Peres et al. 2005). Than et al. (2008) membandingkan tingkat pertumbuhan 3 spesies Colletotrichum yang menginfeksi cabai, pertumbuhan C. gloesporioides ialah $11.2 \mathrm{~mm}$ per hari, $C$. capsici $7.1 \mathrm{~mm}$ per hari, dan C. acutatum $5.8 \mathrm{~mm}$ per hari. Analisis keragaman genetika cendawan penyebab penyakit antraknosa tidak cukup hanya didasarkan pada karakter morfologi. Karakter molekuler seperti sikuen DNA, merupakan indikator yang akurat. Penggunaan primer spesifik $C$. acutatum telah banyak digunakan untuk mengetahui keragaman secara genetika. Primer spesifik $C$. acutatum menggunakan forward primer CaInt2, CgInt dan reverse primer ITS4 dapat membedakan spesies $C$. acutatum dan C. gloeosporioides yang sukar dibedakan secara morfologi (Grahovac et al. 2012). Sepasang primer spesifik juga digunakan untuk mengamplifikasi DNA $C$. acutatum di Inggris dengan produk sebesar $490 \mathrm{pb}$ (Sreenivasaprasad 1996).
Pertumbuhan koloni C. acutatum tergolong lambat, dengan pertambahan diameter koloni berkisar 3.3-7.0 $\mathrm{mm}$ per hari. Martin dan Garcia-Figueres (1999) menyatakan bahwa tingkat pertumbuhan $C$. acutatum relatif lebih lambat $(6.3 \mathrm{~mm}$ per hari) dibandingkan dengan $C$. gloesporioides (13.7 mm per hari). Konidium C. acutatum berbentuk elips dan meruncing pada salah satu ujungnya (Peres et al. 2005) dan berukuran 8.5-16.5 $\mu \mathrm{m} \times 2.5-4 \mu \mathrm{m}$ (Sutton 1992).

Analisis filogenetika $C$. acutatum asal Indonesia memiliki kedekatan dengan isolat asal Thailand. Diduga cendawan ini tersebar ke Indonesia melalui aktivitas impor benih. Thailand merupakan negara eksportir cabai dan paprika terbesar di Asia Tenggara dengan kontribusi sebesar 56.94\% pada tahun 20082012 (Pusdatin 2015).

Asal isolat sangat memengaruhi kemampuan dari setiap isolat untuk menginfeksi buah cabai. Liao et al. (2012) menyatakan bahwa 3 isolat $C$. acutatum menghasilkan ukuran lesio yang berbeda-beda pada 3 spesies cabai ( $C$. annuum, C. baccatum, dan $C$. chinense). Menurut Oh et al. (1999) perbedaan timbulnya gejala dipengaruhi oleh kondisi lingkungan, isolat patogen, genetika tanaman, cara inokulasi, dan karakteristik atau fisiologi tanaman.

Pengetahuan terkait keragaman genetika C. acutatum merupakan laporan pertama di Indonesia. Laporan ini sekaligus menambah informasi mengenai karakter morfologi, molekuler, dan patogenesitas C. acutatum. Pengetahuan mengenai keragaman spesies cendawan dan respons varietas serta virulensi

Tabel 3 Ukuran lesio (mm) dan patogenisitas isolat Colletotrichum acutatum pada 2 spesies cabai

\begin{tabular}{lcc}
\hline Isolat & Ukuran lesio & Tingkat virulensi \\
\hline Capsicum annuum & & \\
KMP 1531 & 4.91 & Sedang \\
TGM 1101 & 3.66 & Sedang \\
BRB 07 & 17.00 & Tinggi \\
Capsicum frutescens & & \\
KMP 1531 & 7.33 & Tinggi \\
TGM 1101 & 11.91 & Tinggi \\
BRB 07 & 19.08 & Tinggi \\
\hline
\end{tabular}


suatu patogen juga merupakan faktor yang penting dalam pemuliaan tanaman karena akan menentukan perkembangan penyakit.

\section{DAFTAR PUSTAKA}

[AVRDC] Asian Vegetable Research and Development Center. 2009. Development of Locally Adapted, Multiple Disease Resistant and High Yielding Chilli (Capsicum annuum) Cultivars for China, India, Indonesia, and Thailand Phase II. Taiwan (TW): AVRDC Publication.

[BPS] Badan Pusat Statistik. 2015. Produksi cabai besar, cabai rawit, dan bawang merah tahun 2014.http://www.bps.go.id/ brs/view/id/1168 [diakses 11 Okt 2016].

[Balitbangtan] Balai Penelitian dan Pengembangan Pertanian. 2016. Pengendalian antraknosa pada tanaman cabai. http://www.litbang.pertanian.go.id/ berita/one/2630/[diakses 11 Okt 2016].

Choi YW, Hyde KD, Ho WH. 1999. Single spore isolation of fungi. Fungal Divers. 3:29-38.

Grahovac M, Indic D, Vukovic S, Hrustc J, Gvozdenac S, Mihajlovic M, Tanovic B. 2012. Morphological and ecological features as differentiation criteria for Colletotrichum species. Zemdirbyste Agriculture. 99(21):89-196.

Johnston PR, Jones D. 1997. Relationships among Colletotrichum isolates from fruitrots assessed using rDNA sequences. Mycologia. 89(3):420-430. DOI: https:// doi.org/10.2307/3761036.

Kim KD, Oh BJ, Yang J. 1999. Differential interaction of a Colletotrichum gloeosporioides isolate with green and red pepper fruits. Pytoparasitica. 27(2):97 -106. DOI: https://doi.org/10.1007/ BF03015074.

Kim SH, Yoon JB, Do JW, Park HG. 2007. Resistance to anthracnose caused by Colletotrichum acutatum in chilli pepper (Capsicum annuum L.). J Crop Sci Biotech. 10(4):277-280.

Liao CY, Chen MY, Chen YK, Wang TC, Sheu ZM, Kuo KC, Chang PFL, Chung KR, Lee MH. 2012. Characterization of three Colletotrichum acutatum isolates from Capsicum spp. Eur J Plant Pathol.133(3):599-608. DOI: https://doi. org/10.1007/s 10658-011-9935-7.

Martin M, Garcia-Figueres F. 1999. Colletotrichum acutatum and Colletotrichum gloeosporioides cause anthracnose on olives. Eur J Plant Pathol. 105(8):733-741. DOI: https://doi.org/10.1023/A:1008785703330.

Oh BJ, Kim KD, Kim YS. 1999. Effect of cuticular wax layers of green and red pepper fruits on infection by Colletotrichum gloeosporioides. J Phytopathol. 147(9):547-552. DOI: https://doi. org/10.1046/j.1439-0434.1999.00407.x.

Park H, Kim B, Lee W. 1990. Inheritance of resistance to anthracnose (Colletotrichum spp.) in pepper (Capsicum annuum L.). II. Genetic analysis of resistance to Colletotrichum dematium [abstrak]. J Kor Soc Hort Sci. 31(3):207-212.

Peres NA, Timmer LW, Adaskaveg JE, Correll JC. 2005. Lifestyles of Colletotrichum acutatum. J Plant Dis. 89(8):784-796. DOI: https://doi.org/10.1094/pd-89-0784.

[Pusdatin] Pusat Data dan Sistem Informasi Pertanian. 2015. Outlook komoditas pertanian subsektor hortikultura cabai. http://epublikasi.setjen.pertanian.go.id/ epublikasi/outlook/2015/Hortikultura/ Outlook\%20Cabai\%202015/files/assets/ common/downloads/Outlook\%20 Cabai\%202015.pdf[diakses 09 Sep 2016]. Ratanacherdchai K, Wang HK, Lin FC, Soytong K. 2007. RAPD analysis of Colletotrichum species causing chilli anthracnose disease in Thailand. J Agric Technol. 3:211-219.

Sambrook J, Fritsch EF, Maniatis T. 1989. Molecular Cloning: a Laboratory Manual. Ed ke-3. New York (US): Cold Spring.

SharmaP, KaurM, Sharma O, SharmaP, Pathania A. 2005. Morphological, pathological and molecular variability in Colletotrichum capsici, the cause of fruit rot of chillies in the subtropical region of North-Western India. J Phytopathol.153(4):232-237. DOI:https://doi.org/10.1111/j.14390434.2005.00959.x. 
Smith BJ, Black LL. 1990. Morphological, cultural and pathogenic variation among Colletotrichum species isolated from strawberry. Plant Dis. 74(1):69-76. DOI:https://doi.org/10.1094/PD-74-0069.

Sreenivasaprasad S, Sharada K, Brown A, Mills P. 1996. PCR based detection of Colletotrichum acutatum on strawberry. Plant Pathol. 45(4):650-655. DOI: https:// doi.org/10.1046/j.1365-3059.1996.d013.x.

Sutton BC. 1992. The genus Glomerella and it's anamorph Colletotrichum. Di dalam: Bailey JA, Jeger MJ, editor. Colletotrichum. Biology, Pathology and
Control. London (UK):CAB International. Hlm 1-24.

Syukur M, Sujiprihati S, Yunianti R, Kusumah DA. 2010. Evaluasi daya hasil cabai hibrida dan daya adaptasinya di empat lokasi dalam dua tahun. J Agr Indones. (38) 1:43-51.

Than PP, Jeewon R, Hyde KD, Pongsupasamit S, Mongkolporn O, Taylor PWJ. 2008. Characterization and pathogenicity of Colletotrichum species associated with anthracnose on chilli (Capsicum spp.) in Thailand. Plant Pathol. 57(3):562-572. DOI:https://doi.org/10.1111/j.13653059.2007.01782.x. 